\title{
Efficiency Wage Hypothesis: The Case Study of Iran's Manufacturing Industries
}

\author{
*Ahmad Jafari Samimi ${ }^{1}$, Saman Ghaderi ${ }^{2}$ \\ ${ }^{1}$ University of Mazandaran, Babolsar, Iran \\ ${ }^{2}$ Sanandaj Branch, Islamic Azad University, Kurdistan, Iran \\ *jafarisa@umz.ac.ir
}

\begin{abstract}
The purpose of this paper is to test the efficiency wage hypothesis for Iran's manufacturing industries at the 4-digit aggregation level of ISIC classification, during 2001-2006. According to the efficiency wage hypothesis, it is logical for some firms to pay wages that are above the market wage. In some cases the mere fact that workers are paid more can make them more productive. In other words, efficiency wages would increase productivity and there is positive relationship between wages and productivity. In this paper, panel data technique has employed to examine the mentioned hypothesis. However, the obtained results contradict the efficiency wage hypothesis for Iran's manufacturing industries. In other words, according to this result, higher wages lead to less efficient performance by the workers of Iran's manufacturing industries.
\end{abstract}

Key Words: Efficiency wage hypothesis, Productivity, Iran's manufacturing industries, Panel data.

\section{Introduction}

One of the key weaknesses of the Keynesian position was the idea that the labour market can stay in disequilibrium for a long period of time-it requires government intervention to fix this problem. Why should this be? Keynes himself did not provide an explanation. He said that wage bargains were conducted in nominal terms rather than real terms and also that this was not rational, but this was how the world worked. The main justification offered for failure of equilibrium in labour market was "sticky wages". Real wages could not be pushed downwards. Observations from the Great Depression and other episodes of long term high unemployment provided empirical support for this idea, but there was no theoretical explanation of why this should be the case. Under pressure from the neoclassical attack in the 70s neo-Keynesians tried to defend the idea of sticky wages. They wanted to find an explanation of why the labour market fails to function like other markets.

One of the main arguments that have been developed in this context is the "Efficiency Wage" hypothesis. The efficiency wage hypothesis (EWH) argues that wages, at least in some markets, are determined by more than simply supply and demand. Specifically, it points to the incentive for managers to pay their employees more than the market-clearing wage in order to increase their productivity or efficiency. This increased labor productivity pays for the higher wages. There are several theories (or "micro foundations") of why managers pay Efficiency Wages (wages above the market clearing rate). Efficiency wage theory, described by Gordon (1990) as the 'rage of the 80s', is surveyed by Yellen (1984), Akerlof and Yellen (1986), Katz (1986, 1988), Haley (1990), Weiss (1991); Akerlof (1979, 2002), and Stiglitz (2002). Solow (1979) provides the basic structure of efficiency wage models. In Solow's model, wage stickiness is in the employer's interest because wage cutting would lower productivity and raise costs. Because the wage enters a firm's short-run production function in a labour-augmenting way, a cost minimizing firm will favor real wage rigidity. This can be demonstrated as follows (Yellen, 1984; Katz, 1988). The modern efficiency wage theories which have been put forward relate in general to the issues of selection and incentives and six categories of efficiency wage theory can be identified: (i) the adverse selection model; (ii) the labour turnover model; (iii) the shirking model ; (iv) the fairness model; (v) Sociological efficiency wage models;(vi) The union threat model.

The present article tests the EWH by using Iran's manufacturing industries data during 2001-2006 at the ISIC 4-digit aggregation level classification. This paper is organized in five sections. After the introduction in the first section, section 2 provides a theoretical background and reviews empirical research of EWH. Section 3 presents model specification and data description. Section 4 considers the empirical results and finally a conclusion will be provided in section 5 . 


\section{Review of Literatures and Empirical Research}

The theory of efficiency wages says that it is logical for some firms to pay wages that are above the market wage. The reasoning behind this theory states that productivity can be related to wages. In other words, in some cases the mere fact that workers are paid more can make them more productive. This means that the total productivity curve at some points can be upward sloping. Of course after some point the curve will flatten out. By drawing a line from the origin you can find the elasticity of a specific point. This makes it easier to determine what point will be most efficient. The most efficient elasticity equals one. Point $\mathrm{x}$ that is the point tangent to the origin and closest to the output axis has the elasticity of one. Looking at the total product curve you see that the wage increase from point $\mathrm{y}$ to $\mathrm{x}$ is very small compared to the increase in output. It is also easy to notice that if you make the large wage increase from point $\mathrm{x}$ to $\mathrm{z}$ the output increase is very small in comparison. Therefore the most efficient point is point $x$ regardless if the supply and demand equilibrium point is below $\mathrm{x}$. Of course if the supply and demand equilibrium is above point $x$ then the efficiency wage doesn't matter, because you will have to pay above the efficiency wage in order to attract workers. There are examples of possible efficiency wages in practice and there are also critics to the approach. Now we will look at why wages would increase workers productivity.

\section{Fig 1: Total Product Curve}

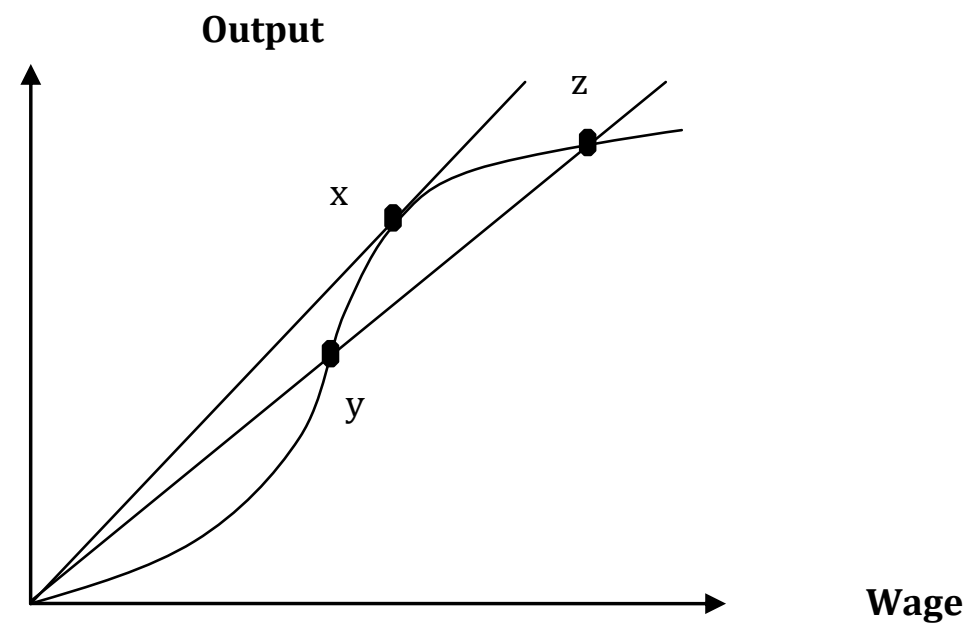

The efficiency wage theory arises from the observation that workers will work harder when firms pay them wages in excess of market levels. If all firms pay above-market wages and refuse to hire workers for less, wage rates in the economy will be above the market-clearing level and unemployment will result. But why would firms not reduce wages, and workers agree to work efficiently at these lower wages, when there is unemployment in the economy? The reason why firms fix the wage rate independently of the reservation wages of workers stems from the assumed production function:

$\mathrm{Y}=\mathrm{F}(\mathrm{e}(\mathrm{w}) \mathrm{n})$

where $\mathrm{Y}$ is output, $\mathrm{e}(\mathrm{w})$ is effort per worker as a function of the real wage rate $w$, and $\mathrm{n}$ is the quantity of labour employed. Notice that e (w) $n$ represents total effort -effort per worker (or per hour) times the number of workers (or hours worked) - and is the single variable input in the production function, capital being present in the background but constant.

To maximize its profits the firm must maximize the excess of output over the variable cost of producing it, the fixed cost of employing capital being constant. This profit function can be written

$\pi=\mathrm{F}(\mathrm{e}(\mathrm{w}) \mathrm{n})-\mathrm{w} \mathrm{n}$

To maximize its profits the firm must choose the levels of $w$ and $n$ for which $\pi$ is a maximum. First order conditions are:

$$
\begin{aligned}
& F^{\prime}(e(w) n) e(w)-w=0 \\
& F^{\prime}(e(w) n) n e ~ '(w)-n=0 \\
& \text { Rearrange }(3): \\
& F^{\prime}(e(w) n)=w / e(w) \\
& \text { Substituting }(5) \text { into }(4): \\
& {[w / e(w)] \text { ne'(w) - } n=0} \\
& \text { Dividing by } n \text { and rearranging: } \\
& {\left[w e^{\prime}(w)\right] /[e(w)]=1}
\end{aligned}
$$


Equation (7) is the well-known "Solow Condition" in the efficiency wage literature. The basis for the Solow Condition can be seen intuitively. If the resulting percentage increase in the level of effort is less than the percentage increase in the real wage it will pay the firm to reduce the wage, the reduction in labour cost being greater than the decline in the value of output produced.

An important implication of this can be seen with reference to Figure 2. The line ww gives the wage rate set by firms according to the Solow condition. At that profit, maximizing wage rate the optimal level of employment of labour by firms happens to be nd units. The quantity of labour time workers wish to supply at that wage rate is ns. There is an equilibrium level of unemployment in the economy of (ns nd). The model implies that there could easily be permanent unemployment.

\section{Fig 2: Efficiency Wage}

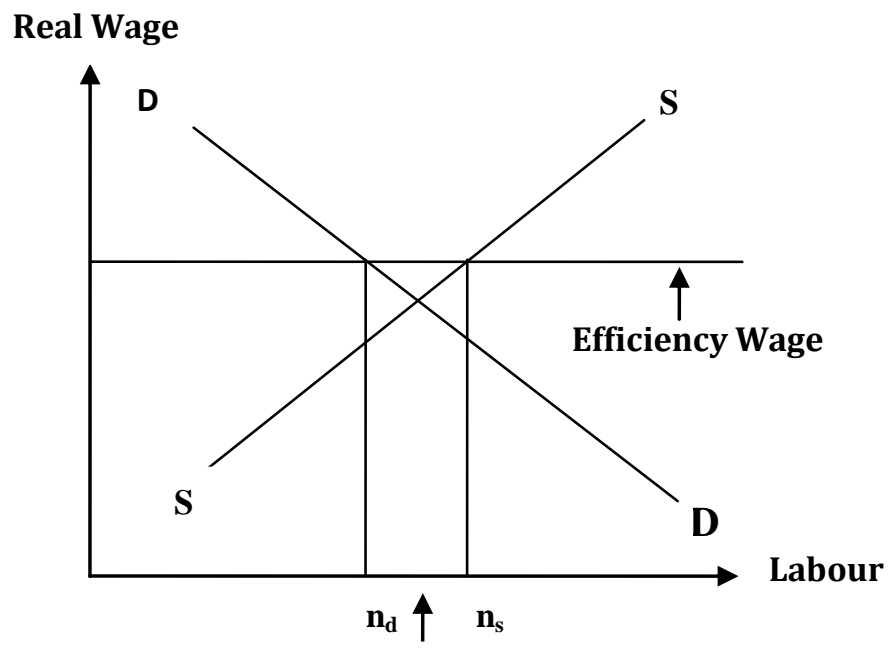

Unemployment

Before proceeding to examine the evidence, we provide some more detail about the efficiency wage hypothesis. The idea that worker productivity and real wages might be positively related over some range was clearly recognized by Alfred Marshall, who observed that 'highly paid labour is generally efficient and therefore not dear labour' (Marshall, 1920). Much later, the efficiency wage idea reappeared in the literature relating to developing economies (Leibenstein, 1957; Bardhan, 1993). In this context higher wages increase the physical well-being of workers through higher nutrition, and by reducing malnourishment higher real wages improve labour efficiency. In the developed-country context, where most workers have adequate nutrition, a different rationale is needed. The modern efficiency wage theories which have been put forward relate in general to the issues of selection and incentives and four categories of efficiency wage theory can be identified: (i) the adverse selection model (for example, Weiss, 1980); (ii) the labour turnover model (for example, Salop, 1979); (iii) the shirking model (for example, Shapiro and Stiglitz, 1984); and (iv) the fairness model (for example, Akerlof, 1982). The reader should note that the papers referred to above (i-iv) are all collected in Akerlof and Yellen (1986).

The adverse selection model: In the adverse selection model, firms that offer higher wages will attract the best workers. Because the labour market is populated by heterogeneous individuals, firms have imperfect information about the productivity characteristics of job applicants; the labour market is an excellent example of a market where asymmetric information predominates. When there is asymmetric information one party to a transaction has more information than the other party. In this case workers have more information about their own abilities, honesty and commitment than employers before they are hired and will attempt to send signals to potential employers that convey information about their qualities, such as educational qualifications, previous employment record and current wage if employed (Spence, 1974, for a discussion of job market signaling).

The labor turnover model: A second reason why firms may offer an efficiency wage in excess of the market-clearing wage is to reduce costly labour turnover. This approach received inspiration from the pioneering work of Phelps (1968) and Phelps (1970) in the development of explanations of the natural rate of unemployment and search behaviour. The idea here is that workers' willingness to quit a job will be significantly reduced if a firm pays above the going rate. With quitting rates a decreasing function of 
the real wage, firms have an incentive to pay an efficiency wage to reduce costly labour turnover. In the model developed by Salop (1979), labour market equilibrium entails involuntary unemployment since all firms need to raise their wages to deter workers from quitting. In situations where unemployment increases, the wage premium necessary to deter labour turnover will fall.

The shirking model: In most occupations, labour contracts are incomplete, which allows workers to exercise discretion with respect to their effort levels. Because contracts cannot specify every aspect of a worker's performance and duties there is 'effort discretion' (Leibenstein, 1979, for a similar approach). Since the collection of information relating to the productivity of individual workers and the continual monitoring of workers is very costly to the firm, the payment of an efficiency wage in excess of the market-clearing equilibrium wage can act as an incentive which will deter the worker from shirking. Such behaviour may be particularly difficult to detect and monitor when teamwork characterizes the workplace. The possibility that workers may vary their effort is a further example of the type of problem that can arise when there is an informational asymmetry present. Workers know more about their effort levels than do their employers. This asymmetry creates a 'principal-agent' problem. An agency relationship develops whenever there is a relationship between economic actors and the welfare of one person depends on the actions of the other party; that is, when the welfare of the principal is influenced by the action (or inaction) of the agent. In the labour market case the principal is the owner of an enterprise and the managers and other workers are the agents. One way of reducing the problem of shirking in this context is to pay an efficiency wage. The threat of dismissal is not an effective deterrent in a labour market where workers can quickly find a new job at the same wage rate. However, if a firm pays a wage in excess of that available elsewhere, or if there is unemployment, workers have an incentive not to shirk, since there is now a real cost to being fired and shirking becomes more risky for each worker. In the Shapiro-Stiglitz (1984) model, the payment of an efficiency wage acts as a disincentive to shirking, and involuntary unemployment in equilibrium is an outcome of the problems firms face when monitoring is imperfect: 'With imperfect monitoring and full employment workers will choose to shirk.' By being paid more than the going rate, workers now face a real penalty if they are caught shirking. But, as Shapiro and Stiglitz (1984) note, 'if it pays one firm to raise its wage it will pay all firms to raise their wages'. Since a rise in the general level of real wages raises unemployment, even if all firms pay the same efficiency wage, workers again have an incentive not to shirk because if caught they will now face the possibility of prolonged unemployment. The 'reserve army' of the unemployed acts as a disincentive device.

The fairness model: In recent years several economists have examined the adverse effects of 'unfair wages' and wage cuts on worker effort via the impact such cuts will have on the morale of the workforce. Sociological models stress such factors as the importance of wage relativities, status, relative deprivation, loyalty, trust and equity. In a series of papers, Akerlof $(1982,1984)$ and Akerlof and Yellen (1990) responded to Solow's (1979) 'piece of home-made sociology' and developed models where feelings about equity and fairness act as a deterrent to firms to offer too low wages in the labour market. Thurow (1983), Blinder (1988) and Solow (1990) have also indicated that this socioeconomic line of enquiry could prove fruitful as an explanation of persistent unemployment.

Sociological efficiency wage models: Solow (1980), drawing on these kinds of concepts, argued that wage rigidity may be at least partly due to social conventions and principles of appropriate behaviour, which are not entirely individualistic in origin. Akerlof (1982) provided the first explicitly sociological model leading to the efficiency wage hypothesis. Using a variety of evidence from sociological studies, Akerlof argues that worker effort depends on the work norms of the relevant reference group. In Akerlof's partial gift exchange model, the firm can raise group work norms and average effort by paying workers a gift of wages in excess of the minimum required, in return for effort above the minimum required.

The union threat model: is one of several explanations for industry wage differentials. This Keynesian economics model looks at the role of unions in wage determination. The degree in which union wages exceed non-union member wages is known as union wage premium and some firms seek to prevent unionization in the first instances. Varying costs of union avoidance across sectors will lead some firms to offer supracompetitive wages as pay premiums to workers in exchange for their avoiding unionization. Under the union threat model, the ease with which an industry can defeat a union drive has a negative relationship with its wage differential. In other words, inter-industry wage variability should be low where the threat of unionization is low. 
Related studies in the context of EWH can be divided into two groups: The first group supports the EWH, but the second one does not provide any support for the mentioned hypothesis. Table 1 represents empirical studies of EWH.

Table 1: Empirical Studies of EWH

\begin{tabular}{llll}
\hline Study & Date & Country & Result \\
\hline Strauss & 1986 & Sierra Leone & support \\
Raff \& Summers & 1987 & USA & support \\
Leonard & 1987 & USA & non-support \\
Romaguera & 1991 & Chile & support \\
Wadhwani and Wall & 1991 & UK & support \\
Levine & 1992 & PIMS data & support \\
Millea & 1998 & USA \& OECD & support \\
Saygili & 1998 & Turkey & support \\
Maloney \& Ribeiro & 1999 & Mexico & support \\
Abbas \& Zaman & 2005 & Pakistan & support \\
Lundborg & 2005 & Sweeden & support \\
\hline
\end{tabular}

Based on the table 1, more empirical studies supported the efficiency wage hypothesis.

\section{Model, Data, and Estimation Methodology}

The present research estimates the EWH for Iran's manufacturing industries using panel data. We have used model similar studies by Wadhwani and Wall (1991), and Levine (1992) as following:

$\log \operatorname{Pr} o d_{i t}=\beta_{1}+\beta_{2} \log W R_{i t}+\beta_{3} \log V A_{i t}+\beta_{4} \log K_{i t}+\beta_{5} \log H C_{i t}+u_{i t}$

$i=1,2, \ldots, N$

$t=1,2, \ldots, T$

$\beta_{2}>0, \beta_{3}>0, \beta_{4}>0, \beta_{5}>0, \beta_{6}>0$

Where dependent variable $\left(\log \operatorname{Pr} o d_{i t}\right)$ shows the logarithm of labour productivity in industry $\mathrm{i}$ and in time t. $\log W R_{i t}$ is the logarithm of real wage. According to the EWH, there is a positive relationship between wages and productivity. Thus, we expect a positive sign for the coefficient of this variable. $\log V A_{i t}$ is the logarithm of real value added and $\log K_{i t}$ is the logarithm of real capital stock. The positive coefficients are expected for these variables. $\log H C_{i t}$ is the logarithm of human capital One modification developed by Huang et al (1998) attempts to assess whether unobserved human capital could also explain the wage-productivity nexus. They argue that some part of the wage is paid by employers to an employee because employees who receive this payment are inherently more educated, motivated and skilled, and therefore, more productive. Thus, the expected sign is positive. In this paper, HC calculated from skilful labor to total productive labor. In this paper, we have used data at the 4-digit aggregation level of ISIC classification during 2001-2006. Raw data have inspired from Centre of Statistic of Iran.

\section{Empirical Results}

In this paper, we use panel data model, and for choosing between OLS the pooled model, Fixed Effects (FE), and Random Effects (RE) we applied the Chow, Lagrange Multiplier (LM) (by Breusch-Pagan) and Hausman tests by Stata 9.1 and Eviews 7. (For more details about panel technique and the related tests, see Baltagi, 2008, Hsiao, 2005 and Gujarati, 2004). Table 2 presents Chow, Lagrange Multiplier and Hausman tests for the model.

Table 2: Chow, Lagrange Multiplier and Hausman Tests

\begin{tabular}{llll}
\hline Test & Test-Statistic & P-value & Result \\
\hline Chow & 34.39 & 0.0000 & FE \\
LM & 202.50 & 0.0000 & RE \\
Hausman & 51.14 & 0.0000 & FE \\
\hline
\end{tabular}


The Chow test is a test for choosing between simple OLS regression and fixed effects that based on table 2 it shows that fixed effects is suitable model. Also, the LM test is to decide between random effects regression and simple OLS regression that result shows random effects regression is appreciated. To decide between fixed or random effects, Hausman test can be run a where the null hypothesis is that the preferred model is random effects vs. the alternative the fixed effects (Green, 2008). Based on information in table 2, the suitable model is fixed effects as presented in table 3.

Table 3: Results of Estimation of Model

\begin{tabular}{|c|c|c|c|}
\hline \multicolumn{4}{|c|}{ Depended Variable: log Productivity } \\
\hline Independent Variable & Coefficient & t-Statistic & Prob. \\
\hline $\log W R$ & -0.8638 & -21.55 & 0.0000 \\
\hline $\log V A$ & 0.9156 & 25.94 & 0.0000 \\
\hline $\log K$ & -0.0161 & -1.87 & 0.0616 \\
\hline $\log \mathrm{HC}$ & 0.0421 & 3.35 & 0.0009 \\
\hline $\mathrm{F}$ & 62.81 & & \\
\hline P-value & 0.0000 & & \\
\hline D.W & 1.78 & & \\
\hline $\mathrm{R}^{2}$ & 0.93 & & \\
\hline $\mathrm{R}^{2}$ Adjusted & 0.91 & & \\
\hline
\end{tabular}

Based on table 3, the coefficient of logWR is negative and statistically significant, but this coefficient does not support the efficiency wage hypothesis. Also, the coefficient of logVA is significant with expected sign but the coefficient of $\log \mathrm{K}$ is the unexpected sign and significant. Based on theory, the coefficient of $\log \mathrm{HC}$ has the expected sign and is statistically insignificant. The F statistic indicates that all the coefficients in the model are different than zero and the model is statistically significant. Also, R-square shows the 93 percent of variance of dependent variable explained by independent variables.

In sum, we can conclude that, according to these results, the EWH does not support for Iran's manufacturing industries. In fact, there are three reasons which help us to explain inconsistency of results with EWH. In the first place, the wages in Iran is rigid and this could cause more involuntarily unemployment. At the same time, there has been a significant increase in labor supply and there is high unemployment in Iran's labor market that the more of these unemployed workers are unskilled workers that they are more inclined to accept any wage level offered to them (below the market-clearing wage) than the rest of the workers. Finally, in contrast to predictions of the efficiency wage theories, high unemployment does not increase productivity in manufacturing industries in Iran and this finding does not support the "Shirking Model" since high levels of unemployment would increase losses from shirking. Alternatively, at sufficiently high levels of unemployment, the loss from being fired may be so high that no one shirks. In such cases, further increases in unemployment would not increase productivity.

\section{Conclusion and Recommendations}

In this paper, we examined the efficiency wage hypothesis (EWH) for Iran's manufacturing industries at the 4-digit aggregation level of ISIC classification during 2001-2006. According to this hypothesis, higher wages lead to more efficient performance by the workers. However, our findings regarding the estimated panel regression analysis contradict the EWH. In other words, according to this result, higher wages lead to less efficient performance by the workers of Iran's manufacturing industries. The high level of unemployment in Iran's labor market is the main reason for inconsistency of the efficiency wage hypothesis. Therefore, the policy implication derived from this empirical study suggests that the government attempts to decrease in unemployment and the firms pay the wages to the workers in excess of the current competitive market wage that these are the effective ways to increase productivity. 


\section{References}

Abbas, S. K., \& Zaman, A. (2005). Efficiency Wage Hypothesis: The Case of Pakistan. The Pakistan Development Review, 44(4), 1051-1066.

Akerlof, G. A. (1982). Labour Contracts as Partial Gift Exchange. Quarterly Journal of Economics, 97(4), 543-63.

Akerlof, G. A. (1984). Gift Exchange and Efficiency-Wage Theory: Four Views. American Economic Review, 74, 79-83.

Akerlof, G. A. (1979). The Case against Conservative Macroeconomics. An Inaugural Lecture. Economica, 46: $219-237$.

Akerlof, G. A. (2002). Behavioural Macroeconomics and Macroeconomic Behaviour. American Economic Review, 92, 411-433.

Akerlof, G. A. and Yellen, J. L. (1986). Introduction in Efficiency Wage Models of the Labor Market. Cambridge University Press, Cambridge.

Akerlof, G. A. \& Yellen, J. L. (1990). The Fair Wage-Effort Hypothesis and Unemployment. Quarterly Journal of Economics, 105 (2), 255-283.

Baltagi, H. B. (2008), Econometric Analysis of panel Data. Johnwiley and Sons, Forth Edition.

Bardhan, P. (1993). Economics of Development and the Development of Economics. Journal of Economic Perspectives, 7(2), 129-142.

Blinder, A. S. (1988). The Challenge of High Unemployment. American Economic Review, 78, 1-15.

Centre of Statistic of Iran, Statistics Yearbook, Various Year, Iran, Tehran.

Gordon, R. J. (1990). What Is New-Keynesian Economics? Journal of Economic Literature, 28(3), 11151171.

Greene, W. (2008). Econometric Analysis, Prentice-hall, Sixth Edition.

Gujarati, D. N. (2004). Basic Econometrics, Forth Edition, McGraw-hill.

Haley, J. (1990). Theoretical Foundations of Sticky Wages. Journal of Economic Surveys, 4, 115-155.

Hsiao, C. (2005). Analysis of panel Data, Cambridge University Press, Second Edition.

Huang, T. L., Hallam, A., Orzem, P. F. \& Paterno, E. M. (1998). Empirical tests of efficiency wage models, Economica, 65, 125-143.

Katz, L. F. (1986). Efficiency Wage Theories: A Partial Evaluation. NBER Macroeconomics Annual, (1), 235290.

Katz, L. F. (1988). Some Recent Developments in Labour Economics and Their Implications for Macroeconomics. Journal of Money, Credit, and Banking, 20(3), 507-522.

Katz, L. F. \& Krueger, A. B. (1999). The High-Pressure Labour Market. Brookings Papers on Economic Activity, 30(1), 1-88.

Leibenstein, H. (1957). The Theory of Underdevelopment in Densely Populated Backward Area, In H. Leibenstein (ed.), Economic Backwardness and Economic Growth. New York: Wiley.

Leibenstein, H. (1979). A Branch of Economics Is Missing: Micro-Micro Theory. Journal of Economic Literature, 17, 477.

Leonard, J. S. (1987). Carrots and Sticks: Pay, Supervision, and Turnover. Journal of Labor Economics, 5, 137-152.

Levine, D. (1992). Can Wage Increases Pay for Themselves? Tests with a Production Function, Economic Journal, 102, 1102-1115.

Lundborg, P. (2005). Individual Wage Setting, Efficiency Wage and Productivity in Sweeden, FIEF Working Paper, 205.

Maloney, W., \& Ribeiro, E. P. (1999). Efficiency Wage and Union Effects in Labor Demand and Wage Structure in Mexico: An Application of Quantile Analysis, Mexico University.

Marshall, A. (1920), Principles of Economics, London: Macmillan.

Millea, M. (1998). A Direct Test of Efficiency Wage Theory: Evidence from U.S. and other OECD Countries, UMI Company, No. 9829528.

Phelps, E. S. (1968). Money Wage Dynamics and Labour Market Equilibrium. Journal of Political Economy, $76(4): 678-711$.

Phelps, E. S. (1970). Microeconomic Foundations of Employment and Inflation Theory, New York: W.W. Norton.

Raff, D., \& Summers, L. (1987). Did Henry Ford pay efficiency wages? Journal of Labor Economics, 5(4), 257-586.

Romaguera, P. (1991). Wage Differentials and Efficiency Wage Models: Evidence from the Chilean Economy. Kellog Institute Discussion Working Paper No. 153.

Salop, S.C. (1979). A Model of the Natural Rate of Unemployment. American Economic Review, 69, 117-25. 
Saygili, Ș. (1998). Is the Efficiency Wage Hypothesis Valid for Developing Countries? Evidence from the Turkish Cement Industry, Studies in Economics, University of Kent at Canterbury, Kent. Discussion Paper, No. 9810.

Shapiro, C. \& Stiglitz, J. (1984). Equilibrium Unemployment as a Worker Discipline Device, American Economic Review, 74, 433-44.

Solow, R. M. (1979). Another Possible Source of Wage Stickiness. Journal of Macroeconomics, 1, 79-82.

Solow, R. M. (1980). On Theories of Unemployment. American Economic Review, 70, 1-11.

Solow, R. M. (1990). The Labor Market as a Social Institution. Basil Blackwell, Cambridge, Massachusetts.

Spence, M. (1974). Market Signalling, Cambridge, MA: Harvard University Press.

Stiglitz, J. E. (2002). Information and Change in the Paradigm in Economics. American Economic Review, 92(3), 460-501.

Strauss, J. (1986). Does Better Nutrition Raise Farm Productivity? Journal of Political Economy, 94, 297320

Thurow, L. C. (1983). Dangerous Currents: The State of Economics, New York: Random House.

Wadhwani, S. B. \& Wall, M. (1991). A Direct Test of the Efficiency Wage Model using UK Micro-Data, Oxford Economic Papers, 43, 529-548.

Weiss, A. (1980). Job Queues and Layoffs in Labour Markets with Flexible Wages. Journal of Political Economy, 88, 526-38.

Weiss, A. (1991). Efficiency Wages: Models of Unemployment, Layoffs and Wage Dispersion, Oxford: Clarendon Press.

Yellen, J. L. (1984). Efficiency Wage Models of Unemployment. American Economic Review, 74(2), 200205. 